\title{
LUMBAR ALTERATIONS IN MAGNETIC RESONANCE: CORRELATION BETWEEN MODIC AND PFIRRMANN CLASSIFICATIONS
}

\author{
ALTERAÇÕES LOMBARES NA RESSONÂNCIA MAGNÉTICA: CORRELAÇÃO ENTRE AS \\ CLASSIFICAÇÕES DE MODIC E PFIRRMANN
}

\section{ALTERACIONES LUMBARES EN LA RESONANCIA MAGNÉTICA: CORRELACIÓN ENTRE LAS CLASIFICACIONES DE MODIC Y PFIRRMANN}

Luciano Miller Reis Rodrigues', Caio Vargas Yoshino', Alexandre Barros Costa ${ }^{1}$

\begin{abstract}
Objective: To evaluate the relationship of sex and age with Modic and Pfirrmann classifications and verify the relationship between the two classifications in the group of patients studied. Methods: 300 magnetic resonance scans (MRI) of the lumbar segment of the patients were evaluated; each lumbar segment (L1-L2, L2-L3, L3-L4, L4-L5 and L5-S1) was assessed according to Modic and Pfirrmann classifications. Results: The type III of Pfirrmann was the most prevalent, whereas Modic was absent on most levels analyzed. The Modic signal was present mainly in the lower levels (L4-L5 and L5-S1) and in females. Conclusion: There is a strong correlation between the changes of the endplate and intervertebral discs, evidenced by changes in MRI. The relationship between Pfirrmann and Modic classifications is statistically higher the greater the disc degeneration.
\end{abstract}

Keywords: Spine, Intervertebral disc, Magnetic resonance imaging.

\section{RESUMO}

Objetivo: Avaliar a relação do sexo e idade com as classificações de Modic e Pfirrmann e verificar a relação entre as duas classificações no grupo de pacientes analisados. Métodos: Foram avaliadas 300 ressonâncias magnéticas (RM) do segmento lombar dos pacientes; cada segmento lombar (L1-L2, L2-L3, L3-L4, L4-L5 e L5-S1) foi avaliado de acordo com as classificações de Modic e de Pfirrmann. Resultados: O tipo III de Pfirrmann foi o mais prevalente, enquanto o Modic estava ausente na maioria dos níveis analisados. O sinal de Modic esteve presente, principalmente, nos níveis mais inferiores (L4-L5 e L5-S1) e no sexo feminino. Conclusão: Existe uma forte correlação entre as alterações da placa terminal e dos discos intervertebrais, evidenciadas pelas alterações na RM. A relação entre as classificações de Pfirrmann e Modic é estatisticamente maior quanto maior for a degeneração discal.

Descritores: Coluna vertebral; Disco intervertebral; Imagem por ressônancia magnética.

\section{RESUMEN}

Objetivo: Evaluar la relación del sexo y edad con las clasificaciones de Modic y Pfirrmann y verificar la relación entre las dos clasificaciones en el grupo de pacientes analizados. Métodos: Fueron evaluadas 300 resonancias magnéticas (RM) del segmento lumbar de los pacientes; cada segmento lumbar (L1-L2, L2-L3, L3-L4, L4-L5 y L5-S1) fue evaluado de acuerdo con las clasificaciones de Modic y de Pfirrmann. Resultados: El tipo III de Pfirrmann fue el más prevalente, mientras que el Modic estaba ausente en la mayoría de los niveles analizados. La señal de Modic estuvo presente, principalmente, en los niveles más inferiores (L4-L5 y L5-S1) y en el sexo femenino. Conclusión: Existe una fuerte correlación entre las alteraciones de la placa terminal y de los discos intervertebrales, evidenciadas por las alteraciones en la RM. La relación entre las clasificaciones de Pfirrmann y Modic es estadísticamente mayor cuanto mayor sea la degeneración discal.

Descriptores: Columna vertebral; Disco intervertebral; Imagen por resonancia magnética.

INTRODUCTION

Magnetic resonance is the method most often used to specifically assess intervertebral disc degeneration. Based on proton density, water content, and chemical environment, it portrays the morphology and hydration of the intervertebral disc. ${ }^{1,2}$ The Modic and Pfirrmann classifications are two known methods used to evaluate degenerative lumbar disease..$^{3,4}$

Dehydration of the nucleus pulposus and changes in the molecular structures of its components start to occur in the third decade of life, at the onset of the disc degeneration process. 5,6

Pfirrmann established his classification in 2001, basing it on criteria of changes in disc morphology in patient MRls (intensity of the signal, structure of the disc, distinction between the nucleus and the annulus, and disc height). ${ }^{7}$
This classification has good applicability in differentiating between the degrees of disc degeneration. ${ }^{8}$ Changes in the end plate were described by Modic ${ }^{9,10}$ in 1988. The studies suggest that changes can progress from one type to another; however, there is limited knowledge about the natural course of the changes reported by Modic. ${ }^{11}$

Despite the structural changes observed in disc degeneration, there is no defined association between the Pfirrmann classification and the changes observed in the vertebral plate used by the Modic classification.

However, both are easy to apply and have high intraobserver agreement. ${ }^{12}$ The objective of this study is to better understand degenerative disc disease and its evolution by establishing a parallel between the two classification systems.

1. Faculdade de Medicina do ABC (FMABC) [ABC School of Medicine], Santo André, SP, Brazil.

Study conducted at the Hospital Estadual Mario Covas, Santo André, SP, Brazil, and by the Discipline of Locomotor Apparatus Diseases of the Faculdade de Medicina do ABC, Santo André, SP, Brazil. Correspondence: Rua Borges Lagoa, 1065, São Paulo, SP, Brazil. CEP 04038-032. luciano.miller@uol.com.br 


\section{METHODS}

We analyzed the MRIs of 300 patients treated between January and December 2011 at the Clinic of Spinal Pathologies of the Hospital Estadual Mario Covas (HEMC), Santo André, SP, Brazil, which is linked to the discipline of Orthopedics and Traumatology of the Faculdade de Medicina do ABC (FMABC). With the patient's consent, a second copy of the MRI exams of the lumbar spine was requested from the Radiology Sector of the HEMC for the study.

The lumbar images (intervertebral discs and end plates from L1 to S1) were analyzed and classified by two doctors of the FMABC Spine Group according to the classifications of Modic and Pfirrmann using the Osirix Image Software (CAntoine Rosset, 2003-2011) program. When there were disagreements, they reevaluated the images until they reached consensus.

To meet the objectives of the study, the variables of sex and age group, and the Modic and Pfirrmann measurements were described for each group of patients using absolute and relative frequencies, and the totals of the classifications of the evaluated levels were presented.

The Pfirrmann and Modic measurements at each vertebral level were described according to sex, then compared between the sexes using Mann-Whitney tests. The scales were also described by age group and compared between the groups using Kruskal-Wallis tests. The Pfirrmann and Modic measurements were described at each vertebral level and the existence of a relationship between the two scales was verified using Spearman correlations. The tests were performed with a significance level of $5 \%$. All the analyses were performed using SPSS for Windows version 15.0.

\section{RESULTS}

Table 1 shows that most of the patients evaluated are female (59\%) and are in the 40-60 years of age group (53\%).

It is observed that Pfirrmann Type III is the most common across all the levels evaluated. (Table 2)

Table 3 shows that the Modic signal is absent in most of the discs evaluated and that Type 2 is more common in discs L3-L4, L4-L5, and L5-S1. There was no Type 3 found.

It was observed that in discs L2-L3 and L3-L4 the Pfirrmann grade is statistically higher in female patients. (Table 4)

It was found that the Modic grade is statistically higher in females and in disc L3-L4. (Table 5)

Table 6 shows that the Pfirrmann grade increases statistically with age group in all discs evaluated $(p<0.05)$, with the exception of disc L5-S1 where the Pfirrmann grade is statistically equal in the three patient age groups ( $p=0.127$ ).

It was observed that the Modic grade increases statistically with age group in discs L3-L4 and L5-S1. (Table 7)

It was found that the higher the Pfirmann grade, the higher the Modic grade, and vice-versa, in all the intervertebral discs evaluated. (Table 8)

Table 1. Description of sex and age group of the patients evaluated.

\begin{tabular}{c|c|c}
\hline Variable & $\mathbf{N}$ & $\%$ \\
\hline Sex & & \\
\hline Female & 178 & 59.3 \\
\hline Male & 122 & 40.7 \\
\hline Age group & & \\
\hline$<40$ years & 56 & 18.7 \\
\hline 40 to 60 years & 160 & 53.3 \\
\hline$>60$ years & 84 & 28.0 \\
\hline Total & 300 & 100 \\
\hline
\end{tabular}

Table 2. Description of Pfirrmann by vertebral levels and the sum of all levels.

\begin{tabular}{c|c|c|c|c|c|c|c|c|c|c|c|c}
\hline \multirow{2}{*}{ Pfirmann } & \multicolumn{2}{|c|}{ L12 } & \multicolumn{2}{|c|}{ L23 } & \multicolumn{2}{c|}{ L34 } & \multicolumn{2}{c|}{ L45 } & \multicolumn{2}{|c|}{ L5S1 } & \multicolumn{2}{c}{ All discs } \\
\cline { 2 - 12 } & $\mathbf{N}$ & $\%$ & $\mathbf{N}$ & $\%$ & $\mathbf{N}$ & $\%$ & $\mathbf{N}$ & $\%$ & $\mathbf{N}$ & $\%$ & $\mathbf{N}$ & $\%$ \\
\hline Type I & 0 & 0.0 & 0 & 0.0 & 0 & 0.0 & 5 & 1.7 & 0 & 0.0 & 5 & 0.3 \\
\hline Type II & 124 & 41.3 & 83 & 27.7 & 53 & 17.7 & 36 & 12.0 & 35 & 11.7 & 331 & 22.1 \\
\hline Type III & 90 & 30.0 & 112 & 37.3 & 122 & 40.7 & 88 & 29.3 & 102 & 34.0 & 514 & 34.3 \\
\hline Type IV & 58 & 19.3 & 73 & 24.3 & 87 & 29.0 & 99 & 33.0 & 93 & 31.0 & 410 & 27.3 \\
\hline Type V & 28 & 9.3 & 32 & 10.7 & 38 & 12.7 & 72 & 24.0 & 70 & 23.3 & 240 & 16.0 \\
\hline Total & 300 & 100 & 300 & 100 & 300 & 100 & 300 & 100 & 300 & 100 & 1500 & 100 \\
\hline
\end{tabular}

Table 3. Description of Modic by vertebral discs and the sum of all levels.

\begin{tabular}{c|c|c|c|c|c|c|c|c|c|c|c|c}
\hline \multirow{2}{*}{ Modic } & \multicolumn{2}{|c|}{ L12 } & \multicolumn{2}{|c|}{ L23 } & \multicolumn{2}{c|}{ L34 } & \multicolumn{2}{c|}{ L45 } & \multicolumn{2}{c|}{ L5S1 } & \multicolumn{2}{c}{ All discs } \\
\cline { 2 - 13 } & $\mathbf{N}$ & $\%$ & $\mathbf{N}$ & $\%$ & $\mathbf{N}$ & $\%$ & $\mathbf{N}$ & $\%$ & $\mathbf{N}$ & $\%$ & $\mathbf{N}$ & $\%$ \\
\hline Absent & 282 & 94.0 & 285 & 95.0 & 266 & 88.7 & 247 & 82.3 & 250 & 83.3 & 1330 & 88.7 \\
\hline Type 1 & 5 & 1.7 & 1 & 0.3 & 3 & 1.0 & 10 & 3.3 & 2 & 0.7 & 21 & 1.4 \\
\hline Type 2 & 13 & 4.3 & 14 & 4.7 & 31 & 10.3 & 43 & 14.3 & 48 & 16.0 & 149 & 9.9 \\
\hline Total & 300 & 100 & 300 & 100 & 300 & 100 & 300 & 100 & 300 & 100 & 1500 & 100 \\
\hline
\end{tabular}

Table 4. Description of Pfirrmann by intervertebral disc according to sex.

\begin{tabular}{|c|c|c|c|c|c|c|c|}
\hline \multicolumn{8}{|c|}{ Sex } \\
\hline \multirow[t]{2}{*}{ Variable } & \multicolumn{2}{|c|}{ Female } & \multicolumn{2}{|c|}{ Male } & \multicolumn{2}{|c|}{ Total } & \multirow[t]{2}{*}{ p } \\
\hline & $N$ & $\%$ & $\mathrm{~N}$ & $\%$ & $\mathrm{~N}$ & $\%$ & \\
\hline Pfirrmann L12 & & & & & & & 0.298 \\
\hline Type II & 71 & 39.9 & 53 & 43.4 & 124 & 41.3 & \\
\hline Type III & 53 & 29.8 & 37 & 30.3 & 90 & 30.0 & \\
\hline Type IV & 32 & 18.0 & 26 & 21.3 & 58 & 19.3 & \\
\hline Type V & 22 & 12.4 & 6 & 4.9 & 28 & 9.3 & \\
\hline Pfirrmann L23 & & & & & & & 0.008 \\
\hline Type II & 43 & 24.2 & 40 & 32.8 & 83 & 27.7 & \\
\hline Type III & 62 & 34.8 & 50 & 41.0 & 112 & 37.3 & \\
\hline Type IV & 49 & 27.5 & 24 & 19.7 & 73 & 24.3 & \\
\hline Type V & 24 & 13.5 & 8 & 6.6 & 32 & 10.7 & \\
\hline Pfirrmann L34 & & & & & & & 0.008 \\
\hline Type II & 31 & 17.4 & 22 & 18.0 & 53 & 17.7 & \\
\hline Type III & 60 & 33.7 & 62 & 50.8 & 122 & 40.7 & \\
\hline Type IV & 57 & 32.0 & 30 & 24.6 & 87 & 29.0 & \\
\hline Type V & 30 & 16.9 & 8 & 6.6 & 38 & 12.7 & \\
\hline Pfirrmann L45 & & & & & & & 0.251 \\
\hline Type I & 5 & 2.8 & 0 & 0.0 & 5 & 1.7 & \\
\hline Type II & 16 & 9.0 & 20 & 16.4 & 36 & 12.0 & \\
\hline Type III & 58 & 32.6 & 30 & 24.6 & 88 & 29.3 & \\
\hline Type IV & 46 & 25.8 & 53 & 43.4 & 99 & 33.0 & \\
\hline Type V & 53 & 29.8 & 19 & 15.6 & 72 & 24.0 & \\
\hline Pfirrmann L5S1 & & & & & & & 0.817 \\
\hline Type II & 17 & 9.6 & 18 & 14.8 & 35 & 11.7 & \\
\hline Type III & 69 & 38.8 & 33 & 27.0 & 102 & 34.0 & \\
\hline Type IV & 50 & 28.1 & 43 & 35.2 & 93 & 31.0 & \\
\hline Type V & 42 & 23.6 & 28 & 23.0 & 70 & 23.3 & \\
\hline Total & 178 & 100 & 122 & 100 & 300 & 100 & \\
\hline $\begin{array}{c}\text { Results of the } \\
\text { Mann-Whitney test }\end{array}$ & & & & & & & \\
\hline
\end{tabular}


Table 5. Description of Modic by intervertebral level according to sex.

\begin{tabular}{|c|c|c|c|c|c|c|c|}
\hline \multicolumn{8}{|c|}{ Sex } \\
\hline \multirow[t]{2}{*}{ Variable } & \multicolumn{2}{|c|}{ Female } & \multicolumn{2}{|c|}{ Male } & \multicolumn{2}{|c|}{ Total } & \multirow[t]{2}{*}{ p } \\
\hline & $\mathbf{N}$ & $\%$ & $\mathbf{N}$ & $\%$ & $\mathbf{N}$ & $\%$ & \\
\hline Modic L12 & & & & & & & 0.873 \\
\hline Absent & 167 & 93.8 & 115 & 94.3 & 282 & 94.0 & \\
\hline Type 1 & 3 & 1.7 & 2 & 1.6 & 5 & 1.7 & \\
\hline Type 2 & 8 & 4.5 & 5 & 4.1 & 13 & 4.3 & \\
\hline Modic L23 & & & & & & & 0.261 \\
\hline Absent & 167 & 93.8 & 118 & 96.7 & 285 & 95.0 & \\
\hline Type 1 & 1 & 0.6 & 0 & 0.0 & 1 & 0.3 & \\
\hline Type 2 & 10 & 5.6 & 4 & 3.3 & 14 & 4.7 & \\
\hline Modic L34 & & & & & & & 0.001 \\
\hline Absent & 149 & 83.7 & 117 & 95.9 & 266 & 88.7 & \\
\hline Type 1 & 3 & 1.7 & 0 & 0.0 & 3 & 1.0 & \\
\hline Type 2 & 26 & 14.6 & 5 & 4.1 & 31 & 10.3 & \\
\hline Modic L45 & & & & & & & 0.420 \\
\hline Absent & 144 & 80.9 & 103 & 84.4 & 247 & 82.3 & \\
\hline Type 1 & 6 & 3.4 & 4 & 3.3 & 10 & 3.3 & \\
\hline Type 2 & 28 & 15.7 & 15 & 12.3 & 43 & 14.3 & \\
\hline Modic L5S1 & & & & & & & 0.100 \\
\hline Absent & 143 & 80.3 & 107 & 87.7 & 250 & 83.3 & \\
\hline Type 1 & 2 & 1.1 & 0 & 0.0 & 2 & 0.7 & \\
\hline Type 2 & 33 & 18.5 & 15 & 12.3 & 48 & 16.0 & \\
\hline Total & 178 & 100 & 122 & 100 & 300 & 100 & \\
\hline
\end{tabular}

Table 6. Description of Pfirrmann by intervertebral disc according to age group.

\begin{tabular}{|c|c|c|c|c|c|c|c|c|c|}
\hline \multirow{3}{*}{ Variable } & \multicolumn{6}{|c|}{ Age group } & & & \multirow{3}{*}{ p } \\
\hline & \multicolumn{2}{|c|}{$<40$ years } & \multicolumn{2}{|c|}{40 to 60 years } & \multicolumn{2}{|c|}{$>60$ years } & \multicolumn{2}{|c|}{ Total } & \\
\hline & $\mathbf{N}$ & $\%$ & $\mathbf{N}$ & $\%$ & $\mathbf{N}$ & $\%$ & $\mathbf{N}$ & $\%$ & \\
\hline Pfirrmann L12 & & & & & & & & & $<0.001$ \\
\hline Type II & 38 & 67.9 & 70 & 43.8 & 16 & 19.0 & 124 & 41.3 & \\
\hline Type III & 12 & 21.4 & 49 & 30.6 & 29 & 34.5 & 90 & 30.0 & \\
\hline Type IV & 6 & 10.7 & 29 & 18.1 & 23 & 27.4 & 58 & 19.3 & \\
\hline Type V & 0 & 0.0 & 12 & 7.5 & 16 & 19.0 & 28 & 9.3 & \\
\hline Pfirrmann L23 & & & & & & & & & $<0.001$ \\
\hline Type II & 35 & 62.5 & 42 & 26.3 & 6 & 7.1 & 83 & 27.7 & \\
\hline Type III & 17 & 30.4 & 63 & 39.4 & 32 & 38.1 & 112 & 37.3 & \\
\hline Type IV & 2 & 3.6 & 41 & 25.6 & 30 & 35.7 & 73 & 24.3 & \\
\hline Type V & 2 & 3.6 & 14 & 8.8 & 16 & 19.0 & 32 & 10.7 & \\
\hline Pfirrmann L34 & & & & & & & & & $<0.001$ \\
\hline Type II & 27 & 48.2 & 24 & 15.0 & 2 & 2.4 & 53 & 17.7 & \\
\hline Type III & 23 & 41.1 & 66 & 41.3 & 33 & 39.3 & 122 & 40.7 & \\
\hline Type IV & 4 & 7.1 & 46 & 28.8 & 37 & 44.0 & 87 & 29.0 & \\
\hline Type V & 2 & 3.6 & 24 & 15.0 & 12 & 14.3 & 38 & 12.7 & \\
\hline Pfirrmann L45 & & & & & & & & & $<0.001$ \\
\hline Type I & 3 & 5.4 & 0 & 0.0 & 2 & 2.4 & 5 & 1.7 & \\
\hline Type II & 18 & 32.1 & 16 & 10.0 & 2 & 2.4 & 36 & 12.0 & \\
\hline Type III & 22 & 39.3 & 42 & 26.3 & 24 & 28.6 & 88 & 29.3 & \\
\hline Type IV & 11 & 19.6 & 62 & 38.8 & 26 & 31.0 & 99 & 33.0 & \\
\hline Type V & 2 & 3.6 & 40 & 25.0 & 30 & 35.7 & 72 & 24.0 & \\
\hline Pfirrmann L5S1 & & & & & & & & & 0.127 \\
\hline Type II & 11 & 19.6 & 20 & 12.5 & 4 & 4.8 & 35 & 11.7 & \\
\hline Type III & 16 & 28.6 & 52 & 32.5 & 34 & 40.5 & 102 & 34.0 & \\
\hline Type IV & 21 & 37.5 & 54 & 33.8 & 18 & 21.4 & 93 & 31.0 & \\
\hline Type V & 8 & 14.3 & 34 & 21.3 & 28 & 33.3 & 70 & 23.3 & \\
\hline Total & 56 & 100 & 160 & 100 & 84 & 100 & 300 & 100 & \\
\hline $\begin{array}{c}\text { Results of the } \\
\text { Kruskal-Wallis test }\end{array}$ & & & & & & & & & \\
\hline
\end{tabular}

Table 7. Description of Modic by intervertebral disc according to age group.

\begin{tabular}{|c|c|c|c|c|c|c|c|c|c|}
\hline \multirow{3}{*}{ Variable } & \multicolumn{6}{|c|}{ Age group } & & & \multirow{3}{*}{$\mathbf{p}$} \\
\hline & \multicolumn{2}{|c|}{$<40$ years } & \multicolumn{2}{|c|}{$\begin{array}{l}40 \text { to } 60 \\
\text { years }\end{array}$} & \multicolumn{2}{|c|}{$>60$ years } & \multicolumn{2}{|c|}{ Total } & \\
\hline & $\mathbf{N}$ & $\%$ & $\mathrm{~N}$ & $\%$ & $\mathbf{N}$ & $\%$ & $\mathbf{N}$ & $\%$ & \\
\hline Modic L12 & & & & & & & & & 0.066 \\
\hline Absent & 56 & 100.0 & 150 & 93.8 & 76 & 90.5 & 282 & 94.0 & \\
\hline Type 1 & 0 & 0.0 & 3 & 1.9 & 2 & 2.4 & 5 & 1.7 & \\
\hline Type 2 & 0 & 0.0 & 7 & 4.4 & 6 & 7.1 & 13 & 4.3 & \\
\hline Modic L23 & & & & & & & & & 0.143 \\
\hline Absent & 56 & 100.0 & 151 & 94.4 & 78 & 92.9 & 285 & 95.0 & \\
\hline Type 1 & 0 & 0.0 & 1 & 0.6 & 0 & 0.0 & 1 & 0.3 & \\
\hline Type 2 & 0 & 0.0 & 8 & 5.0 & 6 & 7.1 & 14 & 4.7 & \\
\hline Modic L34 & & & & & & & & & 0.012 \\
\hline Absent & 56 & 100.0 & 138 & 86.3 & 72 & 85.7 & 266 & 88.7 & \\
\hline Type 1 & 0 & 0.0 & 3 & 1.9 & 0 & 0.0 & 3 & 1.0 & \\
\hline Type 2 & 0 & 0.0 & 19 & 11.9 & 12 & 14.3 & 31 & 10.3 & \\
\hline Modic L45 & & & & & & & & & 0.144 \\
\hline Absent & 51 & \begin{tabular}{|l|}
91.1 \\
\end{tabular} & 128 & 80.0 & 68 & 81.0 & 247 & 82.3 & \\
\hline Type 1 & 2 & 3.6 & 6 & 3.8 & 2 & 2.4 & 10 & 3.3 & \\
\hline Type 2 & 3 & 5.4 & 26 & 16.3 & 14 & 16.7 & 43 & 14.3 & \\
\hline Modic L5S1 & & & & & & & & & 0.009 \\
\hline Absent & 52 & \begin{tabular}{|l|}
92.9 \\
\end{tabular} & 136 & 85.0 & 62 & 73.8 & 250 & 83.3 & \\
\hline Type 1 & 0 & 0.0 & 1 & 0.6 & 1 & 1.2 & 2 & 0.7 & \\
\hline Type 2 & 4 & 7.1 & 23 & 14.4 & 21 & 25.0 & 48 & 16.0 & \\
\hline Total & 56 & 100 & 160 & 100 & 84 & 100 & 300 & 100 & \\
\hline $\begin{array}{c}\text { Results of the } \\
\text { Kruskal-Wallis test }\end{array}$ & & & & & & & & & \\
\hline
\end{tabular}

Table 8. Description of Pfirrmann and Modic by intervertebral disc.

\begin{tabular}{|c|c|c|c|c|c|c|c|c|c|c|}
\hline \multirow{3}{*}{ Disc } & \multirow{3}{*}{ Pfirrmann } & \multicolumn{6}{|c|}{ Modic } & \multirow{2}{*}{\multicolumn{2}{|c|}{ Total }} & \multirow{3}{*}{ p } \\
\hline & & \multicolumn{2}{|c|}{ Absent } & \multicolumn{2}{|c|}{ Type 1} & \multicolumn{2}{|c|}{ Type 2} & & & \\
\hline & & $\mathbf{N}$ & $\%$ & $\mathbf{N}$ & $\%$ & $\mathbf{N}$ & $\%$ & $\mathbf{N}$ & $\%$ & \\
\hline \multirow[t]{5}{*}{ L12 } & Type II & 120 & 42.6 & 0 & \begin{tabular}{|l|}
0.0 \\
\end{tabular} & 4 & 30.8 & 124 & 41.3 & $<0.001$ \\
\hline & Type III & 88 & 31.2 & 2 & 40.0 & 0 & 0.0 & 90 & 30.0 & \\
\hline & Type IV & 56 & $\mid 19.9$ & 0 & \begin{tabular}{|l|}
0.0 \\
\end{tabular} & 2 & 15.4 & 58 & 19.3 & \\
\hline & Type V & 18 & 6.4 & 3 & 60.0 & 7 & 53.8 & 28 & 9.3 & \\
\hline & Total & 282 & 100 & 5 & 100 & 13 & 100 & 300 & 100 & \\
\hline \multirow[t]{5}{*}{$\mathrm{L} 23$} & Type II & 82 & 28.8 & 0 & \begin{tabular}{|l|}
0.0 \\
\end{tabular} & 1 & 7.1 & 83 & 27.7 & 0.003 \\
\hline & Type III & 108 & 37.9 & 0 & \begin{tabular}{|l|}
0.0 \\
\end{tabular} & 4 & 28.6 & 112 & 37.3 & \\
\hline & Type IV & 68 & 23.9 & 0 & 0.0 & 5 & 35.7 & \begin{tabular}{|l|}
73 \\
\end{tabular} & 24.3 & \\
\hline & Type V & 27 & 9.5 & 1 & 100.0 & 4 & 28.6 & 32 & 10.7 & \\
\hline & Total & 285 & 100 & 1 & 100 & 14 & 100 & 300 & 100 & \\
\hline \multirow[t]{5}{*}{ L34 } & Type II & 53 & 19.9 & 0 & \begin{tabular}{|l|}
0.0 \\
\end{tabular} & 0 & \begin{tabular}{|l|}
0.0 \\
\end{tabular} & 53 & 17.7 & $<0.001$ \\
\hline & Type III & 115 & 43.2 & 0 & \begin{tabular}{|l|}
0.0 \\
\end{tabular} & 7 & 22.6 & 122 & 40.7 & \\
\hline & Type IV & 72 & 27.1 & 0 & 0.0 & 15 & 48.4 & 87 & 29.0 & \\
\hline & Type V & 26 & 9.8 & 3 & 100.0 & 9 & 29.0 & 38 & 12.7 & \\
\hline & Total & 266 & 100 & 3 & 100 & 31 & 100 & 300 & 100 & \\
\hline \multirow[t]{6}{*}{ L45 } & Type I & 5 & 2.0 & 0 & \begin{tabular}{|l|}
0.0 \\
\end{tabular} & 0 & \begin{tabular}{|l|}
0.0 \\
\end{tabular} & 5 & 1.7 & $<0.001$ \\
\hline & Type II & 36 & 14.6 & 0 & \begin{tabular}{|l|}
0.0 \\
\end{tabular} & 0 & \begin{tabular}{|l|}
0.0 \\
\end{tabular} & \begin{tabular}{|l|}
36 \\
\end{tabular} & 12.0 & \\
\hline & Type III & 78 & 31.6 & 4 & 40.0 & 6 & 14.0 & 88 & 29.3 & \\
\hline & Type IV & 85 & 34.4 & 0 & \begin{tabular}{|l|}
0.0 \\
\end{tabular} & 14 & 32.6 & 99 & 33.0 & \\
\hline & Type V & 43 & 17.4 & 6 & 60.0 & 23 & 53.5 & 72 & 24.0 & \\
\hline & Total & 247 & 100 & 10 & 100 & 43 & 100 & 300 & 100 & \\
\hline \multirow[t]{5}{*}{ L5S1 } & Type II & 33 & \begin{tabular}{|l|}
13.2 \\
\end{tabular} & 0 & \begin{tabular}{|l|}
0.0 \\
\end{tabular} & 2 & 4.2 & 35 & \begin{tabular}{|l|}
11.7 \\
\end{tabular} & $<0.001$ \\
\hline & Type III & 94 & 37.6 & 0 & \begin{tabular}{|l|}
0.0 \\
\end{tabular} & 8 & 16.7 & 102 & 34.0 & \\
\hline & Type IV & 89 & 35.6 & 0 & \begin{tabular}{|l|}
0.0 \\
\end{tabular} & 4 & 8.3 & 93 & 31.0 & \\
\hline & Type V & 34 & 13.6 & 2 & 100.0 & 34 & 70.8 & \begin{tabular}{|l|}
70 \\
\end{tabular} & 23.3 & \\
\hline & Total & 250 & 100 & 2 & 100 & 48 & 100 & 300 & 100 & \\
\hline $\begin{array}{l}\text { Results of } \\
\text { Spearman's } \\
\text { correlation }\end{array}$ & & & & & & & & & & \\
\hline
\end{tabular}




\section{DISCUSSION}

This study proposes a correlation between the classifications presented based on analyses of magnetic resonance images, the exam of choice for the visualization of changes in soft tissue (intervertebral disc, ligament, and musculature).

The average age of the patients in this study is between 40 and 60 years, compatible with earlier studies in which the onset of symptoms can be associated with degenerative pathologies, given that disc degeneration is an inevitable consequence of the human aging process. During the evolution of degeneration, the disc becomes more vulnerable to inflammatory processes. ${ }^{13-15}$

Zuo et $a /^{16}$ considered discs with a Pfirrmann grade lower than or equal to type II to be normal, and those with a Pfirmann grade higher than type II to be degenerated. They also observed greater degeneration in disc L4-L5 compared with the other intervertebral segments, similar to the results of our study. ${ }^{16}$ According to the literature, the fact that level L4-L5 has greater mobility may result in greater disc degeneration as compared to the other intervertebral segments. ${ }^{17,18}$

There was also a smaller number of discs classified as type I, due to the patients' age and the fact that they had histories of low back problems.

In relation to the Modic scale, there were no changes at the higher levels (L12 and L23). Where present, changes were observed mainly at the lower levels (L4-L5 and L5-S1), with type 2 being most prevalent, a phenomenon similar to that encountered by Modic et al. ${ }^{4,9,19}$ This is probably because the lower levels are exposed to higher biomechanical stress loads, resulting in changes in the end plates. ${ }^{20}$ In the study, most patients did not present Modic type changes (88.7\%). In accordance with the findings of Leite et al $(88.3 \%)^{21}$, no Modic type 3 changes were observed, a situation that is uncommon. 9,22,23

Previous studies demonstrated similar relationships in terms of the frequency and location of Modic changes in the intervertebral discs studied. Kuisma et $\mathrm{al}^{24}$, studying MRI changes in middle-aged manual laborers, showed that $85 \%$ of the discs at the lower lumbar levels (L5S1) were affected by some change to the end plate (Modic 1 or 2 ). They did not find any type 3 changes. ${ }^{9}$ Takatalo et $\mathrm{a}{ }^{25}$, who studied changes in the MRls of young adults, found a low incidence of the appearance of changes, similar to the findings of our study, with higher prevalence in men, and they also noted a higher incidence in the lower discs. The study by Schenk et al26 showed similar results, with an incidence of around $85 \%$ of end plates without any changes and a low incidence of Modic type 3 changes in a group of health care workers whose jobs required, or did not require physical labor.

In this study, changes in the end plate were more prevalent in females, and even though there was some disagreement about whether gradation between the different Modic types exists, ${ }^{4,9}$ there was a higher prevalence of type 2 changes among females.

In a comparison of the changes in relation to age, it was observed that increasing age coincides with more serious Modic and Pfirrmann type changes. When the two classifications were correlated, the data showed a strong association, showing that the higher the Pfirrmann grade, the higher the Modic changes.

The study was designed to evaluate only the images, without correlating them with the patient's clinical history, symptoms, or social aspects involved. Prior studies suggest a correlation between symptoms and more advanced grades of the classifications studied. ${ }^{14}$ Studies correlating the radiographic findings and symptoms could be topics for further research.

\section{CONCLUSION}

The ideal classification system for degenerative disc disease should be simple, easily applicable, and highly reproducible. There is a strong correlation between changes in the end plates and the intervertebral discs, as evidenced by changes in the MRI. The greater the level of disc degeneration, the closer the relationship between the Pfirrmann and Modic classification systems.

All authors declare no potential conflict of interest concerning this article.

\section{REFERENCES}

1. Tertti M, Paajanen $H$, Laato $M, A$, $H$, Komu M, Kormano M. Disc degeneration in magnetic resonance imaging. A comparative biochemical, histologic, and radiologic study in cadaver spines. Spine (Phila Pa 1976). 1991;16(6):629-34.

2. Viikari-Juntura E Raininko R, VidemanT, Porkka L. Evaluation of cervical disc degeneration with ultralow field MRI and discography. An experimental study on cadavers. Spine (Phila Pa 1976). 1989;14(6):616-9.

3. Griffith JF, Wang YX, Antonio GE, Choi KC, Yu A, Ahuja AT, et al. Modified Pfirrmann grading system for lumbar intervertebral disc degeneration. Spine (Phila Pa 1976). 2007:32(24):E708-12.

4. Hutton MJ, Bayer JH, Powell JM. Modic vertebral body changes: the natural history as assessed by consecutive magnetic resonance imaging. Spine (Phila Pa 1976). 2011;36(26):2304-7.

5. Nguyen AM, Johannessen W, Yoder JH, Wheaton AJ, Vresilovic EJ, Borthakur A, et al. Noninvasive quantification of human nucleus pulposus pressure with use of T1rho-weighted magnetic resonance imaging. J Bone Joint Surg Am. 2008;90(4):796-802.

6. Gruber HE, Hanley EN Jr. Analysis of aging and degeneration of the human intervertebral disc. Comparison of surgical specimens with normal controls. Spine (Phila Pa 1976) 1998:23(7):751-7.

7. Pfirrmann CW Metzdorf A Zanetti M, Hodler J, Boos N Magnetic resonance classification of lumbar intervertebral disc degeneration. Spine (Phila Pa 1976). 2001;26(17):1873-8.

8. Ueno FH, Rodrigues LM, Valesin Filho ES, Puertas EB. Reprodutibilidade intra e inter-observadores da classificação de Pfirrmann para degeneração discal por meio da ressonância magnética.Coluna/Columna. 2008;7(4):330-3.

9. Modic MT, Steinberg PM, Ross JS, Masaryk TJ, Carter JR. Degenerative disk disease: assessment of changes in vertebral body marrow with MR imaging. Radiology. 1988;166:193-9

10. Modic MT, Masaryk TJ, Ross JS, Carter JR. Imaging of degenerative disk disease. Radiology. 1988;168(1):177-86

11. Braithwaite I, White J, Saifuddin A, Renton P, Taylor BA. Vertebral end-plate (Modic) changes on lumbar spine MRI: correlation with pain reproduction at lumbar discography. Eur Spine J. 1998;7(5):363-8.

12. Jones A, Clarke A, Freeman BJ, Lam KS, Grevitt MP. The Modic classification: inter- and intraobserver error in clinical practice. Spine (Phila Pa 1976). 2005:30(16):1867-9.

13. Boos N, Weissbach S, Rohrbach H, Weiler C, Spratt KF, Nerlich AG. Classification of age-related changes in lumbar intervertebral discs: 2002 Volvo Award in basic science. Spine (Phila Pa 1976). 2002;27(23):2631-44

14. Miller JA, Schmatz C, Schultz AB. Lumbar disc degeneration: correlation with age, sex and spine level in 600 autopsy specimens. Spine (Phila Pa 1976). 1988;13(2):173-8.

15. Siemionow K, An H, Masuda K, Andersson G, Cs-Szabo G. The effects of age, sex, ethnicity, and spinal level on the rate of intervertebral disc degeneration: a review of 1712 intervertebral discs. Spine (Phila Pa 1976). 2011;36(17):1333-9.

16. Zuo J, Saadat E, Romero A, Loo K, Li X, LinkTM, et al. Assessment of intervertebral disc degeneration with magnetic resonance single-voxel spectroscopy. Magn Reson Med. 2009;62(5):1140-6.

17. Fujiwara $\mathrm{A}$, An HS, Lim TH, Haughton VM. Morphologic changes in the lumbar intervertebral foramen due to flexion-extension, lateral bending, and axial rotation: an in vitro anatomic and biomechanical study. Spine (Phila Pa 1976). 2001;26(8):876-82.

18. Koeller W, Meier W, Hartmann F. Biomechanical properties of human intervertebral discs subjected to axial dynamic compression. A comparison of lumbar and thoracic discs. Spine (Phila Pa 1976). 1984:9(7):725-33.

19. Ohtori S, Yamashita M, Yamauchi K, Inoue G, Koshi T, Suzuki M, et al. Change in Modic type 1 and 2 signals after posterolateral fusion surgery. Spine (Phila Pa 1976). 2010;35(12):1231-5.

20. de Schepper El, Damen J, van Meurs JB, Ginai AZ, Popham M, Hofman A, et al. The association between lumbar disc degeneration and low back pain: the influence of age, gender, and individual radiographic features. Spine (Phila Pa 1976). 2010;35(5):531-6.

21. Leite MS, Luciano RP, Martins DE, Wajchenberg M, Puertas EB. Correlação entre as classificações de Pfirrmann e Modic na degeneração do disco intervertebral lombar. Coluna/ Columna. 2010:9(4):401-6.

22. Zhao JG, Zhang P, Zhang SF, Qi F, Huang WJ, Xia YZ, et al. Modic type III lesions and Schmorl's nodes are the same pathological changes? Med Hypotheses. 2010 Mar;74(3):524-6.

23. Zhang YH, Zhao CQ, Jiang LS, Chen XD, Dai LY. Modic changes: a systematic review of the literature. Eur Spine J. 2008;17(10):1289-99.

24. Kuisma M, Karppinen J Niinimäki J Ojala $R$, Haapea M, Heliövaara M, et al. Modic changes in endplates of lumbar vertebral bodies: prevalence and association with low back and sciatic pain among middle-aged male workers. Spine (Phila Pa 1976). 2007;32(10):1116-22.

25. Takatalo J, Karppinen J, Niinimäki J, Taimela S, Näyhä S, Järvelin MR, et al. Prevalence of degenerative imaging findings in lumbar magnetic resonance imaging among young adults. Spine (Phila Pa 1976). 2009:34(16):1716-21.

26. Schenk P, LäubliT, Hodler J, Klipstein A. Magnetic resonance imaging of the lumbar spine: findings in female subjects from administrative and nursing professions. Spine (Phila Pa 1976). 2006;31(23):2701-6. 